\title{
SURVEY WITH CHECKLIST OF THE INVASIVE INSECTS TO IRAQ
}

\author{
Razzaq Shalan Augul* and Hanaa H. Al-Saffar \\ Entomology and Invertebrates Department, Iraq Natural History Research \\ Center and Museum, University of Baghdad, Baghdad, Iraq \\ "Corresponding author: dr.rsha@nhm.uobaghdad.edu.iq
}

Received Date: 20 January 2019, Accepted Date: 11 April 2019, Published Date: 27 June 2019

\section{ABSTRACT}

The survey and checklist of invasive species of the insects in some different localities of Iraq are revised; 24 invasive species were documented until December 2018 during the current investigations. The species distributions, common names and synonyms are given.

The current investigation included all of exotic species in Iraq, which are not collected during this study.

Keyword: Insects, Invasive, Iraq, Species, Survey.

\section{INTRODUCTION}

The climate modification is expected to change the geographical distribution and abundance of many species; increase the invasion of new areas by exotic species and in some cases lead to the extinction of some species and whole ecosystems (Gutierrez and Ponti, 2014). According to Pimentel et al. (2000), the invasive species collectively cause, in excess of $140 \$$ billion, in losses annually in the USA, and a trillion globally (Oerke and Dehne, 2004); on the other hand, the invasive of species insects may cause damage to the biodiversity of a region, which is made up of three aspects: compositional, functional and structural diversity (Noss, 1990).

The compositional diversity which means the number of different species in a system is most frequently accepted as a measure for this term; however, the functional and structural diversities are an integral part of the system dynamics, and are frequently severely altered by biological invasions. These species impacts are frequently recorded to affect more than one facet, or where one facet has been affected, the others feel ripple effects; these impacts include replacement of diverse systems with single or mixed species stands of aliens, alteration of geomorphological processes, soil chemistry and hydrology; also invasions may lead to the extinction of compositional diversity and the direct threat to native fauna (Cronk and Fuller, 1995).

For the reasons above, this paper is done because of the absence of any checklist related to invasive insects in the ecosystems of Iraq. 


\section{MATERIALS AND METHODS}

The specimens of this study were collected from different localities of Iraq from January 2013 to December 2018; the sweeping and aerial net, light traps, tephry traps, yellow-sticky traps, lures, baits, and forceps were used to collect the specimens. Some of the collected specimens were put in alcohol (ethanol 75\%) mixed with few drops of glycerin to avoid the change to dark color, such as the larvae of Diptera, but the others were pinned directly such as Coleoptera, adult of flies or indirectly by insect cards; the information concerning the date of collection, locality of the specimens are given.

Many keys Many keys were used to identify the specimens that including: Curran (1965), Zumput (1965), Usinger (1966), Endrodi (1985), Spradbery (1992), White and Elson-Harris (1994), Povolny (1994), Yassin and David (2010), Gasca-Álvarez and Amat-García (2010) and Irish et al. (2014); for precise identification, they were compared with previously identified specimens stored at Iraq Natural History Research Center and Museum, University of Baghdad.

\section{RESULTS AND DISCUSSION}

The current survey from different regions of Iraq for the period 2013-2018 and previous studies showed 24 species belonging to 21 genera, 18 families and 6 orders that have invaded Iraq till the end of December 2018: these species are:

\section{(A) Order: Diptera}

1- Family: Calliphoridae

Chrysomya bezziana (Villeneuve, 1914)

Common name: Old world screwworm fly (OWS).

Hosts: Cattles and human.

Materials examined: (31 specimens): Karbala province, Al-Hindiya District, 11 larvae from sheep, specimens, 31.III.2018. Diyala province (20 specimens), Kifri district, 13 larvae from sheep, 13.IV.2017; Al Khalis district, 7 larvae from dogs, 13.XI.2016.

Distribution: Iraq (Abdul-Rassoul et al., 1996); most tropical and subtropical areas of Africa, Indian Subcontinent, New Guinea and South East Asia (Norris and Murray, 1964; Zumpt, 1965; Sutherst et al., 1989; Rohela et al., 2006). Kuwait, Qatar and Bahrain (Rajapaksa and Spradbery, 1989), Iran (Djalayer et al., 1978; Navidpour et al., 1996); Saudi Arabia (Alahmed, 2002).

2-Family: Drosophilidae

Zaprionus indianus (Gupta, 1970)

Synonyms: Zaprionus collarti Tsacas, 1980

Zaprionus inermis Seguy, 1938

Zaprionus paravittiger Godbole \& Vaidya, 1972

Common name: The African fig fly.

Hosts: Fermented fruits.

Materials examined: (20 specimens): Baghdad, Bab Al Muadham, 10 specimens, 10.III.2018; Al-Kadhimiya, 10 specimens, 22.IV.2018.

Distribution: Semi-cosmopolitan, Florida and Panama (van der Linde et al., 2006); Mexico (Castrezana, 2007); Canada (Renkema et al., 2013); Indian subcontinent (Yassin et al., 2008); Iraq (Al T'oma and van der Linde, 2010) France (Kremmer et al., 2017).

3-Family: Tephritidae

Ceratitis capitata (Wiedemann, 1824) 


\section{Razzaq Shalan Augul and Hanaa H. Al-Saffar}

Synonyms: Ceratitis citripeda Efflatoun, 1924

Ceratitis citriperda Macleay, 1829

Ceratitis hispanica Breme, 1842

Pardalaspis asparagi Bezzi, 1924

Tephritis capitata Wiedemann, 1824

Trypeta capitata (Wiedemann, 1824)

Common name: Mediterranean fruit fly.

Hosts: Citrus plants, pear, grape, tomato, pepper and pomegranate and more than 260 host plants (Steck, 2006).

Materials examined (124 specimens): Wasit province, Numaniyah, 36 specimens, 21.XI.2018; Baghdad province, Bab Al Muadham, 17 specimens, 11.X.2018, Abu Ghraib, 11 specimens, 3. XI.2018 ; Karbala province, Imam Aun district, 27 specimens, 15.V.2018; Diyala province, Baquba city, 21 specimens, 30.XI.2018, Abu Saida district, 12, 20.XI.2018 Distribution: Invasive to Iraq (Al-Haidary, 1947). It irradiated and appeared again as outbreak in Abu Saida district, Diyala province at 2006 in citrus orchids (AL-Jiboory, 2007) Also distributed in: Mauritius, Reunion, Seychelles, North Africa, Southern Europe, Middle East, Western Australia, South and North America (EPPO, 2011a); Ghana, Togo, Benin, Nigeria (De Meyer et al., 2013).

Dacus ciliates Loew, 1862

Synonyms: Dacus brevistylus Bezzi, 1908

Dacus insistens Curran, 1927

Tridacus mallyi Munro, 1925

Common names: Ethiopian fruit fly and cucurbit fly.

Hosts: The larvae of this species grow in the fruits of a wide range of cucurbit crops, such as cucumbers and melons; and wild Cucurbitaceae.

Materials examined: (100 specimens): Baghdad province, 20 specimens, Al-Jadryia, 22.VII. 2018 Abu-Gharaib, 25 specimens, 28.VII.2018; Karbala province 30 specimens, AlHussainya, 10.XI.2018; Wasit province, Numaniyah, 25 specimens, 22.X.2018.

Distribution: Iraq (Moanas and Abdul-Rassoul, 1989); Bangladesh, India, Iran, Myanmar, Pakistan, Saudi Arabia, Yemen, Angola, Egypt, Benin, Botswana, Cameroon, Chad, Eritrea, Ethiopia, Kenya, Lesotho, Madagascar, Malawi, Mauritius, Mozambique, Namibia, Rwanda, Senegal, Sierra Leone, Somalia, South Africa, Sudan, Tanzania, Uganda, Zaire, Zambia, Zimbabwe (IIE, 1995); Benin, Ghana, Guinea Nigeria, Togo (De Meyer et al., 2013).

Dacus frontalis Beecker, 1922

Synonyms: Dacus scopatus Munro, 1948

Dacus ciliates var. duplex 1932

Dacus duplex Munro, 1932

Common name: Lesser pumpkin fly, melon fly.

Hosts: Cucumbers and pumpkins.

Materials examined: (150 specimens): Baghdad province, 20 specimens, Al-Taji 22.X.2018; Karbala province, Imam Aun, 30 specimens, 11.XI.2018; Diyala, Balad Ruz, 50 specimens, 22.XII.2018; Al Madaen, Al Tuwatha, 50 specimens, 15. I.2019.

Distribution: Iraq (Al-Saffar, 2011); Angola, Botswana, Cape Verde Is., Congo, Eritrea, Kenya, Lesotho, Namibia, Saudi Arabia, South Africa,, Tanzania, Yemen, Zimbabwe (White, 2006 ); Sudan (White and Goodger, 2009); Benin, Guinea, (De Meyer et al., 2013); Tunisia (Hafsi et al.,2015); Algeria, Egypt, Libya, Morocco ( El Harym and Belqat, 2017).

Bactrocera zonata (Saunders, 1841)

Synonyms: Bactrocera maculigera Doleshall, 1858 (misidentification) 
Dacus mangiferae Cotes, 1893

Dacus persicus (Biggott, 1890)

Dasyneura zonatus Saunders, 1942

Rivellia persicae Bigot, 1889

Common name: Peach fruit fly.

Hosts: It has a wide range of host plants, which include: berries, fruit, nuts and vegetables; this species can strike many fruits, including guavas, mangoes, peach, apricots, figs and citrus (EPPO, 2002).

Materials examined (20 specimens): Baghdad, AL-Jadryia, 22.V.2018.

Distribution: In Iraq as Dacus zonata registered by E 1- Haidari et al. (1972) and Al-Ali (1977), Bactrocera zonata by Abdulrazak et al. (2016); also, this species distributes in Saudi Arabia, Yemen, Oman, Mauritius, Iran (White, 2002); Egypt (El-Gendy, 2002).

\section{(B)Order: Hemiptera}

1- Family: Aleyrodidae

Aleuroclava jasmine (Takahashi, 1932)

Synonyms: Aleurotuberculatus jasmine Takahashi, 1932

Iceria purchasi Kaussari, 1957

Iceria purchasi Kiritchenko, 1932

Icerya pulchasi Chou, 1947

Common name: Jasmine whitefly.

Hosts: Polyphagous plant, it's reached about 20 species; a minor pest of citrus and some ornamentals.

Distribution: Egypt (Amin et al., 1997); Australia (Martin, 1999); India (Sundararaj, 1999); China (Luo and Zhou, 2001); Iraq (Al-Shamary, 2004).

\section{2- Family: Cimicidae}

Cimex hemipterus (Fabricius, 1803)

Common name: Tropical bed bugs.

Hosts: Humans.

Materials examined (5 specimens): Baghdad, Al- Hurriyah district, 24.II.2018

Distribution: Tropical and subtropical regions (Ibrahim et al., 2017); Iraq (Hussain, 1963. Abul -Hab, 1979).

Cimex lectularius Linnaeus, 1758

Common name: Bed bugs.

Hosts: Humans other mammals (like bats).

Material Examined (10 specimens): Baghdad, Al- Chikuk, 5 specimens, 20.I.2018; Al-Taji, 3 specimens, 22.II.2018, Al-Hurriya, 2 specimens, 4.IV.2018.

Distribution: Cosmopolitan distributed (Usinger, 1966); in Iraq this species was registered by Abul-Hab (1980); Malaysia (Ab Majed and Zahran, 2015).

3- Family: Coccidae

Parasaissetia nigra (Niether, 1861)

Synonyms: Coccus nigrum Kirkaldy, 1902

Lecanium caudatum Green, 1896

Common names: Pomegranate scale, nigra scale, black coffee scale, hibiscus shield scale. Hosts: Fig, coffee, and many crops.

Distribution: Iraq (Abdul-Rassoul and Al-Mallo, 2016); Asia: Bangladesh, India, Saudi Arabia, Indonesia and Yemen; Africa: Egypt, Eretria, Ghana and Uganda; Europe: France, Portugal and Spine (Cheraghian, 2014). 


\section{Razzaq Shalan Augul and Hanaa H. Al-Saffar}

\section{4- Family: Diaspididae}

Duplachionaspis graminella (Borchsenius, 1949)

Synonyms: Chionaspis graminis Archangelskaya, 1937

Chionaspis phragmitidis Borchsenius, 1949

Chionaspis graminella Borchsenius, 1949

Duplachionaspis phragmitidis Balachowsky, 1954

Chionaspis graminellus Alimdzhanov and Bronshtein, 1956

Common name: Armord scale insect.

Hosts: Poceae, Phragmites australis (Cav.)

Distribution: Iraq (Jabbar et al., 2016); Uzbekistan (Borchsenius, 1949); Taiwan (Alimdzhanov, and Bronshtein,1956); Afghanistan (Danzig, 1972); Turkmenistan (Myartseva, 1982); Saudi Arabia (Matile-Ferrero, 1988); Iran (Moghaddam, 2013).

\section{5- Family: Margarodidae}

Icerya purchasi Maskell, 1878

Common name: Cottony cushion scale.

Hosts: This scale insect feeds on more than 65 families of woody plants, most notably on the species the belonging to the genera Citrus and Pittosporum.

Distribution: Iraq (Bodenheimer, 1951); this insect widespread throughout the world wherever citrus is grown (Ebeling, 1959); Slovakia (Kollár et al., 2016).

\section{6- Family, Pseudococcidae}

Nipaecoccus viridis (Newstead, 1894)

Synonyms: Dactylopius viridis Newstead, 1894

Dactylopius vastator Maskell, 1895

Nipaecoccus vastator Ferris, 1950

Common names: Spherical and Lebbeck mealybug.

Hosts: In Iraq this species registered on Citrus species; but this species is a widespread and greatly polyphagous pest, which attacks more than 100 species of herbaceous and woody plants (Sharaf and Meyerdirk, 1987).

Distribution: Iraq (Abdul-Rassoul, 1971); widespread throughout Africa and Asia (CABI, 2007). Native to Asia and widespread throughout the tropics and subtropics (Ben-Dov et al., 2010; Florida (Stocks, 2010); Rajasthan (Babu, 2016).

Phenacoccus solenopsis Tinsley, 1898

Synonym: Phenacoccus cevalliae Cockerell, 1902

Common name: Cotton mealybug.

Hosts: Polyphagous pest on different hosts like field crops, horticultural, fruit, vegetable and ornamental plants.

Materials examined (57 specimens): Baghdad province, 22 specimens from cape jasmine (Family, Rubiaceae), Al- Karrada Al-Sharqiya, 10.VII. 2015; 35 specimens from Pilea Lindley (1821) (Urticaceae), Al-Rubaie district, 13 specimens, 29.VI.2015 and 22 specimens collected at 2.VII.2016.

Distribution: New Mexico (Tinsley, 1898), and it spread to Caribbean and Ecuador (Ben Dov, 1994), Chile (Larrain,2002), Argentina (Granara de Willink, 2003), Brazil (Culik and Guallan, 2005), Pakistan (Abbas et al., 2005), India (Yousuf et al., 2007), Nigeria (Akintola and Ande, 2008), Sri Lanka (Prishanthini and Laxmi, 2009), Australia (Admin, 2010), Egypt (Abd-Rabou et al., 2010), Indonesia (Muniappan et al., 2011), Iran (Moghaddam and Bagheri, 2011), Cyprus (EPPO, 2011 b), Turkey (Kaydan et al., 2013), Japan (Tanaka and Tabata, 2014); Iraq (Abdul-Rassoul et al., 2015). 
(C) Order: Lepidoptera

1-Family: Gelechiidae

Tuta bsoluta (Meyrick, 1917)

Synonyms: Gnorimoschema absoluta (Meyrick, 1917)

Phthorimaea absoluta (Meyrick, 1917)

Scrobipalpula absoluta (Meyrick, 1917)

Scrobipalpuloides absoluta (Meyrick, 1917)

Common names: Tomato leafminer and tomato pinworm.

Hosts: The larvae of T. absoluta attacks tomato leaves, buds, stems and fruits, and this plant is the main host, but this pest also attacks other crops such as Solanaceous including: potato, eggplant, pepper, and pepino; tree tobacco, lambs-quarters and bindweed are also hosts (Desneux et al., 2010); recently there are many registered as a new host plants, including: common beans and broad bean, cowpea, wild radish, tobacco, cape gooseberry and goji berry (EPPO, 2009), also the alfalfa plant is reported as a new host to this pest by AbdulRassoul (2014).

Materials examined (45 specimens): Wasit province (33 specimens from tomato in plastic houses), 10 specimens, Al-Aziziyah district, 2.V.2016; Dibuni district, 23 specimens, 11.VI.2016. Baghdad province, Al-Mada'in district, 12 specimens, 20.IV.2017.

Distribution: Native to South America and has been recorded from Argentina, Bolivia, Brazil, Chile, Colombia, Ecuador, Paraguay, Peru, Uruguay and Venezuela (Cabello et al., 2012); Spain (Urbaneja et al., 2007), and has subsequently spread throughout the Mediterranean Basin and Europe (Potting, 2009); it is currently an agricultural threat to European and North African tomato production (Desneux et al., 2010). In Iraq this species reported by Abdul-Razzak et al. (2010).

\section{2- Family: Gracillariidae}

Phyllocnistis citrella Stainton, 1856

Common name: Citrus leaf miner.

Hosts: Citrus plants that including: orange, lime, lemon, and tangerine; other Rutaceae recorded as hosts in different regions such as: Aegle marmelos (L.) Corr. Serv. (Fletcher, 1920), Murraya paniculata (L.) Jack. (Pruthi and Mani, 1945) and Poncirus trifoliata (L.) Raf. (Clausen, 1933) in India; Atalantia sp. in the Philippines (Sasscer, 1915).

Distribution: This species is described from India (Stainton, 1856); Iraq (Bodenheimer, 1951); it distributed from East Africa: Sudan to Yemen (Badawy, 1967), and through southern Asia: Saudi Arabia to India (Fletcher, 1920), Hong Kong and China and Philippines (Sasscer, 1915); Taiwan (Chiu, 1985); Japan (Clausen, 1927). It is also found in New Guinea and nearby Pacific Islands $(C A B, 1970)$. Mexico and several Caribbean islands (Jones, 2001); USA and Hawaii (Nagamine and Heu, 2003); Australia (Beattie and Hardy, 2004).

\section{(D) Order: Coleoptera}

1-Family: Chrysomelidae

Leptinotarsa decemlineata (Say, 1824)

Synonym: Doryphora decemlineata Say, 1824

Common name: Colorado potato beetle.

Host: Potato.

Materials examined (15 specimens): Dohuk province, Sumail district, 4 specimens, 22.VIII.2013; Sersink district, 11 specimens, 11.VIII.2013.

Distribution: It occurs in Mexico, United States, Canada; this species has been introduced into Europe and parts of Asia (Capinera, 2001). Iraq (El-Jboory, 2004). 
Razzaq Shalan Augul and Hanaa H. Al-Saffar

2-Family: Curculionidae

Rhynchophorus ferrugineus (Olivier, 1790)

Synonyms: Curculio ferrugineus Olivier, 1790

Cordylesex maculatus Thunberg, 1797

Calandra ferruginea Fabricius, 1801

Rhynchophorus signaticollis Chevrolat, 1882

Common names: Red palm weevil, Red stripe weevil and Asian palm weevil.

Hosts: Date palm, coconut palm and oil palm.

Distribution: Burma, China, Egypt, India, Indonesia, Iran, Malaysia, Pakistan, Papua New

Guinea, Philippines, Saudi Arabia, Sri Lanka, Taiwan, Thailand, Tanzania, UAE, Jordan,

Palestine and Vietnam (Zaid, 1999); Iraq (Aletby, 2016); Malta (Mizzi et al., 2009).

3-Family: Dynastidae

Oryctes sahariensis De Mire, 1960

Common name: Rhinoceros beetles.

Host: Palm.

Distribution: Iraq (Al-Saeedi, 2015); Egypt (Carpenter, 1975); Chad and Sudan (Carpenter and Elmer, 1978); Qatar (Mokhtar, 2009).

4- Family: Scarabaeidae

Maladera castanea (Arrow, 1913)

Synonym: Autoserica korgei Petrovitz, 1967

Common name: Asiatic garden beetle.

Hostes: Crops, ornamentals, turfgrass, sweet potatoes, soy beans, corn.

Distribution: Japan (Fujiyama, 1983); Korea, China Russian Far East (Ahrens, 2007); Atlantic Canada (Culter and Rogers, 2009); Florida (Skelley, 2012); India (Bhwane et al., 2012); Iraq (Al-Jamali et al., 2017).

Maladera insanbilis (Brenske, 1894)

Synonyms: Maladera matrida Argaman, 1986

Autoserica adiuncta Brensk, 1897

Autoserica esfandiiarii Petrovitz, 1970

Serica immutabilis Burmeister, 1855

Common names: White grub beetle.

Hosts plant: It is a polyphagous pest on ornamental and fruit plants.

Distribution: Iraq (Al-Jassany et al., 2016), Mediterranean region and Libya (Ahrens et al., 2006); Egypt (Karam and El-Minshawy, 2016); Saudi Arabia (Abdel-Dayem et al., 2017).

\section{(E) Order: Hymenoptera}

1- Family: Eulophidae

Leptocybe invasa Fisher \& LaSalle, 2004

Common names: Australian gall wasp, blue gum chalcid.

Host: Eucalyptus sp.

Distribution: Iraq (Hassan, 2012); Middle east and Africa (Mendel et al., 2004); Wylie and Speight (2012) stated that species of L. invasa is native to Queensland, Australia, and presently distributed through Africa, Asia and the Pacific, Europe, Latin America and the Caribbean, Near East and North America.

2- Family: Ichneumonidae

Cryptus inculcator (Linnaeus, 1758)

Synonyms: Cryptus albopictus Seyrig, 1928 
Cryptus lippensis Rudow, 1883

Cryptus filicornis Ratzeburg, 1844

Cryptus quadrilineatus Gravenhorts, 1829

Cryptus sponsor (Fabricius, 1794)

Itamoplex inculcator (Linnaeus, 1758)

Itamoplex sponsor (Fabricius, 1793)

Host: Greater wax moth.

Distribution: Iraq (Al-Jassany et al., 2012); Ireland (O' Connor et al., 2007); Iran (Barahoei et al., 2015, Mohebban et al., 2015); England (Broad, 2016).

(F) Order: Thysanoptera

Family: Thripidae

Thrips palmi Karny, 1925

Synonyms: Thrips clarus Moulton, 1928

Thrips leucadophilus Priesner, 1936

Thrips gossypicola Ramakrishna \& Margabandhu, 1939

Chloethrips aureus Ananthakrishnan \& Jagadish, 1967

Thrips gracilis Ananthakrishnan \& Jagadish, 1968

Common name: Melon thrips.

Hosts: It is a polyphagous pest on vegetables, especially in the Solanaceae and Cucurbitaceae.

Distribution: Iraq (Hamodi and Abdul-Rassoul, 2012); (Bhatti, 1980); India (Rajulu and Gowri, 1988); Malaysia (Mound and Azidah, 2009).

\section{LITERATURE CITED}

Abbas, G., Arif, M. J. and Saeed, S. 2005. Systematic status of a new species of the genus Phenacoccus Cockerell (Pseudococcidae), a serious pest of cotton Gossypium hirsutum L. in Pakistan. Pakistan Entomologist, 27: 83-84.

Abdel-Dayem, M. S., Fad, H. H., El-Torkey, A. M., Elgharbawy, A. A., Aldryhim, Y. N., Kondratieff, C. B., Al Ansi, A. N. and Aldhafer, H. M. 2017. The beetle fauna (Insecta, Coleoptera) of the Rawdhat Khorim National Park, Central Saudi Arabia. Zookeys, 653: 1-78.

Abd-Rabou S., Germain, J. F. and Malausa, T. 2010. Phenacoccus parvus Morrison et $P$. Solenopsis Tinsley, deux Cochenilles nouvelles pour 1'Egypte (Hemiptera: Pseudococcidae). Bulletin de la Socie'te' Entomoloque de France, 115(4): 509-510.

Abdul-Rassoul, M. S. 1971. Notes on the parasites and predators of Nipaecoccus vastator (Maskell) from Iraq. Bulletin of the Iraq Natural History Museum, 5(1): 19-21.

Abdul-Rassoul, M. S. 2014. A new host record for tomato leaf miner Tuta absoluta (Meyric, 1917) in Baghdad province, Iraq. Bulletin of the Iraq Natural History Museum, 13(1): $15-18$.

Abdul-Rassoul, M. S. and Al-Malo, I. M. 2016. First record of nigra scale, Parasaissetia nigra (Niether,1861) (Hemiptera; Coccidae) as pest of fig trees in Iraq. Bulletin of the Iraq Natural History Museum, 14(2): 171-178. 


\section{Razzaq Shalan Augul and Hanaa H. Al-Saffar}

Abdul-Rassoul, M. S., Ali. H. A. and Jassim, F. A. 1996. Notes on Chrysomya bezziana Villeneuve (Diptera, Calliphoridae) first record from Iraq. Bulletin of the Iraq Natural History Museum, 8(4): 113-115.

Abdul-Rassoul, M. S., Al-Malo, I. M. and Hermiz, F. B. 2015. First record and host plants of Solenopsis mealybug, Phenacoccus solenopsis Tinsley, 1898 (Hemiptera: Pseudococcidae) from Iraq. Journal of Biodiversity and Environmental Sciences, 7(2): 216-222.

Abdul Razzak, A. S., Al-Yasiri, I. I. and Fadhil, H. Q. 2010. First record of tomato borer (tomato moth) Tuta absoluta (Meyrick) (Lepidoptera: Gelechiidae) on tomato crop in Iraq. Arab and Near East Plant Protection Newsletter, 51: 31.

Abdulrazak, A. S., Hadwan, H. A., Hassan, S. A., Aydan, N. I. and Mohammed, A. K. 2016. New record of peach fruit fly Bactrocera zonata (Saunders) (Tephritidae: Diptera) in Iraq. Arab and Near East Plant Protection Newsletter, 69: 3. Available at: http://www.asplantprotection.org/PDF/ANEPPN/ANEPPNL69En.pdf

Ab Majid, A. H. and Zahran, Z. 2015. Resurgence of tropical bed bug, Cimex hemipterus (Hemiptera: Cimicidae) infestation in Malaysia: Control strategies and challenges faced by urban pest control operator (PCO). Journal of Entomology and Zoology Studies, 3(3): 419-422.

Abul-Hab, J. 1979. On the bed bugs (Hemiptera, Cimicidae) in Iraq. Iraq Bulletin of the Endemic Diseases, 19 (1-4): 65-76.

Abul-Hab, J. K. 1980. A list of arthropoda of medical and veterinary importance recorded from Iraq. Bulletin of Biological Research Center, 12(1): 9-39.

Admin. 2010. Exotic mealybug species-a major pest in cotton. Available at: http:// the beatsheet.com.au/ mealybugs/exotic mealybug species a major new pest in cotton.

Ahrens, D. 2007. Taxonomic changes and an updated catalogue for the Palaearctic Sericini (Coleoptera: Scarabaeidae: Melolonthinae). Zootaxa, 1504: 1-51

Ahrens, D., Arnone, M. and Massa, B. 2006. Maladera insanabilis (Brenske, 1894), invasive species in the Mediterranean region and its distribution in Libya (Coleoptera, Scarabaeidae, Sericini). Il Naturalista siciliano, 30: 349-357.

Akintola, A. J. and Ande, A. T. 2008. First record of Phenacoccus solenopsis Tinsley (Hemiptera: Pseudococcidae) on Hibiscus rosasinensis in Nigeria. Agricultural Journal (Medwell Journals, Pakistan), 3(1): 1-3.

Alahmed, A. M. 2002. Incidence of myiasis in sheep caused by Chrysomya bezziana Saudi Arabia. Journal of King Saud University, 14: 109-112.

Al-Ali, A. 1977. Phytophagous and entomophagous insects and mites of Iraq. Natural History Research Center, Publication, 33: 1-142. 


\section{Survey with checklist of the invasive}

Aletby, M. A. A. W. 2016. First record of red palm weevil, Rhynchophorus ferrugineus (Olivier, 1790) on the date palm, Phoenix dactylifera in Basrah, Iraq. Basrah Journal of Agricultural Sciences, 29(1): 1-6.

Al-Haidary, D. 1947. The fruit fly (Mediterranean fruit fly). The Journal of Iraqi Agriculture, 2(4): 229-225. (In Arabic).

Alimdzhanov, R. A. and Bronshtein, T. G. 1956. Coccoidea. Invertebrate animals of the Zeravshan Basin. $100^{\text {th }}$ Akad. Nauk Uzbek. Tashkent, 348 pp.

Al-Jamali, N. A., Abu-Digha, A. B. and Al-Ghazali, N. A. 2017. New record of the asiatic garden beetle, Maladera castanea (Arrow) (Coleoptera: Scarabaeidae ) in the ornamental Nurseries in Karbala - Iraq. Journal of Kerbala University, 13(1): 102107.

Al-Jassany, R. F., Al-Malo, I. M. and Dawi, H. I. 2012. New record of the parasitoid, Cryptus inculcator (L.) on larvae and pupa of greater wax moth in Iraq. The Iraqi Journal of Agricultural Sciences, 43(1): 71-76.

Al-Jassany, R. F., Al-Malo, E. M. and Al-Juboory, A. B. 2016. A new recording of the rose beetle Maladera insanabilis (Coleoptera: Scarabeidae) on some ornamental and fruit plants in Iraq. International Journal of Agriculture and Crop Sciences, 4: 172174

Al-Jiboory, I. J. 2007. Ceratitis capitata (Wiedeman) (Diptera: Tephritidae) Mediterranean fruit fly (Medfly), Disaster pest in citrus and other fruits orchards. Leaflet, 43pp. (In Arabic).

Al- Saffar, H. H. 2011. Taxonomic study of fruit fly family: Tephritidae (Insecta: Diptera) from some governorates of Iraq. Ph.D. Thesis in Sciences of Biology- Zoology, Collage of Science, University of Baghdad, 179 pp. (In Arabic).

Al-Shammary, N. 2004. Studies on the jasmine whitefly, Aleuroclava jasmine with some methods of control. M.Sc. Thesis, Department of Plant Protection, Collage of Agriculture, University of Baghdad, 159 pp. (In Arabic).

Al-Saeedi, H. M. L. 2015. Survey for species of genus Oryctes spp. (Coleoptera: Dynastidae) in middle and south of Iraq and evaluation some methods for their control. M. Sc. Thesis, Department of Plant Protection, College of Agriculture, University of Baghdad, 139 pp. (In Arabic).

Al T'oma, Z. A. M. and van der Linde, K. 2010. First records of Zaprionus indianus (Diptera: Drosophilidae) from the Basra governorate in Iraq. Drosophella Information Service, 93: 197-200.

Amin, A. H., Emam, A. K. and Helmi, A. 1997. A new record on a whitefly species of the genus Aleurotuberculatus (Homoptera: Aleyrodidae) on citrus trees in Egypt. Mededelingen Faculteit Landbouwkundige en Toegepaste Biologische Wetenschappen Universiteit Gent, 62(2a): 349-354. 


\section{Razzaq Shalan Augul and Hanaa H. Al-Saffar}

Babu, S. R. 2016. Note on the occurrence of spherical mealybug, Nipaecoccus viridis (Newstead) and their parasitoids on soybean in southern Rajasthan. Current Biotica, 9(4): 373-375.

Badawy, A. 1967. The morphology and biology of Phyllocnistis citrella Staint., a citrus leaf miner in the Sudan. Bulletin of the Entomological Society of Egypt, 51: 95-103.

Beattie, A. and Hardy, S. 2004. Citrus leafminer. Department of Primary Industries, Industry \& Investment New South Wales. Available at: http://www.dpi.nsw.gov.au/__data/assets/pdf_file/0006/137634/citrus-leafminer.pdf.

Barahoei, H., Nader, F. and Rakhshani, E. 2015. Cryptinae (Hymenoptera: Ichneumonidae) fauna of Isfahan Province of Central Iran. Turkish Journal of Zoology, 39: 279-284.

Ben-Dov, Y. 1994. A systematic catalogue of the mealybugs of the world (Insecta: Homoptera: Coccoidea: Pseudococcidae and Putoidae) with data on geographical distribution, host plants, biology and economic importance. Intercept Limited, Anover, UK, 686pp.

Ben-Dov, Y., Miller, D. R. and Gipson, G. A. P. 2010. ScaleNet. Available at: http://www.sel.barc.usda.gov/catalog s/pseudoco/Nipaecocusviridis.htm

Bhatti, J. S. 1980. Species of the genus Thrips from India (Thysanoptera). Systematic Entomology, 5(2): 109-166.

Bhawane, G. P., Mamlayya, A. B., Wagh, S. R. and Chaugule, A. K. 2012. Diversity of white grub beetles and their host range from Northern Western.Ghats, Kolhapur district (MS) India. The Bioscan, 7(4): 589-596.

Bodenheimer, F. S. 1951. Citrus entomology in the Middle East, with special references to Egypt, Iran, Irak, Palestine, Syria, Turkey. The Netherland Press, Hoistema BrotherGroninger (Holad), 664pp.

Borchsenius, N. S. 1949. A new genus and new species of hard and soft scales (Homoptera, Coccoidea) of USSR fauna. Entomologicheskoe Obozrenye, 30: 334-353.

Broad, G. R. 2016. Checklist of British and Irish Hymenoptera - Ichneumonidae. Biodiversity, 4: e9042. doi: 10.3897/BDJ.4. e9042

CAB. 1970. Commonwealth Agricultural Bureaux, Commonwealth Institute of Entomology. Phyllocnistis citrella Stnt. In: Distribution maps of pests. Ser. A, Map No. 274. The Eastern Press Ltd., London.

CABI. 2007. Crop Protection Compendium. Commonwealth Agricultural Bureau International (CABI), Wallingford, UK.

Cabello, T., Gallego, J. R., Fernandez, F. J., Gamez, M., Vila, E. and Del Pino, M. 2012. Biological control strategies for the south american tomato moth (Lepidoptera: Gelechiidae) in greenhouse tomatoes. Journal of Economic Entomology, 105: 20852096.

Capinera, J. L. 2001. Handbook of vegetable pests. San Diego, CA: Academic Press, 729pp. 
Survey with checklist of the invasive

Carpenter, J. B. 1975. Notes on date culture in the Arab Republic of Egypt, Israel and the people's democratic republic of Yemen. Date Growers' Institute Report, 52: 18-24.

Carpenter, J. B. and Elmer, H. S. 1978. Pests and diseases of the date palm. United States Department of Agriculture, Agriculture Handbook, 527: 1- 42.

Castrezana, S. 2007. New records of Zaprionus indianus Gupta, 1970 (Diptera, Drosophilidae) in North America and a key to identify some Zaprionus species deposited in the Drosophila Tucson Stock Center. Drosophila Information Service, 90: 34-36.

Cheragian, A. 2014. A guide for diagnosis and detection of quarantine pests, pomegranate scale Parasaissetia nigra (Nietner, 1861) Hemiptera: Coccidae. Islamic Republic of Iran. Ministry of Jihad-e-Agriculture Plant Protection Organization, 9 pp.

Chiu, S. C. 1985. Biological control of citrus pests in Taiwan. Taiwan Agricultural Research Institute, Special Report, 19: 1-8.

Clausen, C. P. 1927. The citrus insects of Japan. USDA, Washington, D.C., Technical Bulletin, 15: 1-15.

Clausen, C. P. 1933. The citrus insects of tropical Asia. USDA, Washington, D.C. Circular, 266: 1-35.

Cronk, Q. C. B. and Fuller, J. C. 1995. Plant invasions: the threat to natural ecosystems. Chapman and Hall, London, xiv +241 pp.

Culik, M. P. and Gullan, P. J. 2005. A new pest of tomato and other records of mealy bugs (Hemiptera: Pseudococcidae) from Espirito Santo, Brazil. Zootaxa, 964:1-8.

Curran, C. H. 1965. The families and genera of North American Diptera. $2^{\text {ed }}$ rev. ed. Henry Trip, 515 pp.

Cutler, G. C. and Rogers R. E. L. 2009. New record of the asiatic garden beetle, Maladera castanea (Arrow), in Atlantic Canada. Journal of the Entomological Society of Ontario, 140: 40-45.

Danzig, E. M. 1972. Contributions to the knowledge of the scale insects fauna (Homoptera, Coccoidea) of Afghanistan. Entomologicheskoe Obozrenye, 51: 581-584.

De Meyer, M., White, I. M. and Goodger, K. F. M. 2013. Notes on the frugivorous fruit fly (Diptera: Tephritidae) fauna of western Africa, with description of a new Dacus species. European Journal of Taxonomy, 50: 1-17. doi: 10.5852/ejt.2013.50

Desneux, N., Wajnberg, E., Wyckhuys, K. A. G., Burgio, G., Arpaia, S. C. A., Narva'ezVasquez, S. C. A., lez-Cabrera, J. G., Ruescas, D. C., Tabone, E., Frandon, J. Pizzol, J., Poncet, C., Cabello,T. and Urbaneja, A. 2010. Biological invasion of European tomato crops by Tuta absoluta: ecology, geographic expansion and prospects for biological control. Journal Pest Science, 83: 197-215.

Djalayer, T., Maleki, M. and Moghtader, M. 1978. Human urogenital myiasis caused by Chrysomyia bezziana. Iranian Journal of Public Health, 7: 116-119. 


\section{Razzaq Shalan Augul and Hanaa H. Al-Saffar}

Ebeling, W. 1959. Subtropical fruit pests. University of California Press, Los Angeles, 436 pp.

El-Gendy, I. R. 2002. Stidieson peach fruit fly. Bactrocera zonata at el-Behira Governorate. M.Sc. Thesis, Faculty of Agriculture, Alexandria University, 127pp.

El-Haidari, H., Fattah, Y. and Sultan, J. 1972. Contribution to the insect fauna of Iraq, Part 4. Ministry Agricultura Iraq Bulletin, 18: 1- 17.

El Harym, Y. and Belqat, B. 2017. First checklist of the fruit flies of Morocco, including new records (Diptera, Tephritidae). ZooKeys, 702: 137-171. doi: 10.3897/zookeys.702.13368

El-Jboory, I. 2004. A new potato pest in Northern Iraq: Disease and pest outbreaks - Iraq. Arab and Near East Plant Protection Newsletter, 38: 27.

Endrodi, S. 1985. The Dynastinae of the world. First edition, Vol. 28; Springer Netherlands, 842pp.

EPPO. 2002. Bactrocera zonata: introduction into the EPPO region and its identification by Dr Ian M. White. Available at: https:// www.eppo.int/ACTIVITIES/plant_quarantine/shortnotes_qps/bactrocera_zonata

EPPO. 2009. Tuta absoluta found on Phaseolus vulgaris in Sicilia (IT), EPPO Reporting Service no. 08 - 2009 Num. article: 2009/154. Available at: https://gd.eppo.int/reporting/article-342.

EPPO. 2011a. Ceratitis capitata. Available at: https://gd.eppo.int/download/standard/228/pm7-104-1-en.pdf

EPPO. 2011b. New pest records in EPPO member countries. EPPO Reporting Service 4, 2011/082. Available at: https://gd.eppo.int/reporting/article-199.

Fletcher, T. B. 1920. Life histories of Indian insects, Microlepidoptera. Memoirs of the Department of Agriculture in India, 6: 1-217.

Fujiyama, S. 1983. The larval diapause of three Scarabaeid beetles and its function in their life cycles. In: Brown, V. K. and Hodek, I. (eds.). Diapause and life cycle strategies in insects. Dr. W. Junk Publisher, The Hague, Netherlands, pp. 55-66.

Gasca-Álvarez, H. J. and Amat-García, G. 2010. Synopsis and key to the genera of Dynastinae (Coleoptera, Scarabaeoidea, Scarabaeidae) of Colombia. ZooKeys, 34: 153-192.

Granara de Willink, M. C. 2003. New records and host plants of Phenacoccus sp. for Argentina (Hemiptera: Pseudococcidae). Revta Sociedad Entomologia Argentina, 62: 80-82.

Gutierrez, A. P. and Ponti L. 2014. Analysis of invasive insects: links to climate change. In: Ziska, L. H. and Dukes J. S. (eds.), Invasive species and global climate change. CABI Publishing, Wallingford, UK, p 45-61. DOI 10.1079/9781780641645.0045 
Survey with checklist of the invasive

Hafsi, A., Abbes, K., Harbi, A., Ben Othman, S., Limem, E., Ksantini, M. and Chermiti, B. 2015. The pumpkin fly Dacus frontalis (Diptera: Tephritidae): A new pest of curcubits in Tunisia. Bulletin OEPP/EPPO Bulletin, 45(2): 209-213.

Hamodi, A. A. and Abdul-Rssoul, M. S. 2012. New record of Thrips palmi Karny, 1925 (Thysanoptera: Thripidae) in Iraq. Arab Journal of Plant Protection, 30(1): 142-144.

Hassan, F. 2012. First record of the Eucalyptus gall wasp, Leptocybe invasa Fisher and La Salle (Hymenoptera: Eulophidae), in Iraq. Acta Agrobotanica, 65(3): 93-98.

Hussain, A. A. 1963. Provisional list of insect pests and bibliography of insect fauna of Iraq. Bulletin Collage Sciences, 7: 43-83.

Irish, S., Lindsay, T. and Wyatt, N. 2014. Key to adults of Afrotropical species of the genus Chrysomya Robineau-Desvoidy (Diptera: Calliphoridae). African Entomology, 22(2): 297-306.

Ibrahim, O., Syed, U. M. and Tomecki, K. J. 2017. Bedbugs: Helping your patient through an infestation. Cleveland Clinic Journal of Medicine, 84(3): 207211. Doi:10.3949/ccjm.84a.15024

IIE. 1995. Distribution maps of pests, Series A, no. 323 (1st revision). CAB International, Wallingford, UK.

Jabbar, A. S., Abdul-Qhader, A. A. and Al-Ebadi, H. M. T. 2016. New record of scale insects species in Iraq. Journal of Misan Researches, 12(23): 40-54.

Jones, J. 2001. Citrus leafminer. Arizona crop information site. Available at: http://ag.arizona.edu/crops/crops.html.

Karam, H. H. and El-Minshawy, A. M. 2016. Maladera insanabilis (Brenske, 1894), (Coleoptera, Scarabaeidae, Melolonthinae, Sericini): A new horticultural pest in Egypt. Alexandria Journal of Agricultural Sciences, 16(5): 487-489.

Kaydan, M. B., Çaliskan, A. F. and Ulusoy, M. R. 2013. New record of invasive mealybug Phenacoccus solenopsis Tinsley (Hemiptera: Pseudococcidae) in Turkey. EPPO Bulletin, 43(1): 169-171.

Kollár, J., Bakay, L. and Pástor, M. 2016. First Record of the cottony cushion scale Iceryapurchasi (Hemiptera, Monophlebidae) in Slovakia. Plant Protection Science, 52(3): 1-3.

Kremmer, L., David, J., Borowiec, N., Thaon, M., Ris, N., Poorie, M. and Gatti, J. L. 2017. The african fig fly Zaprionus indianus: a new invasive pest in France. Bulletin of Insectology, 70(1): 57-62.

Larrain, S. P. 2002. Insect and mite pest incidence on sweet pepinos Solanum muricatum (Ait.) cultivated in the IV Region, Chile. Agricultura-Tecnica, 62(1): 15-26.

Luo, Z. and Zhou, C. M. 2001. Record of the citrus whiteflies in China. [Chinese] South China Fruits, 30(1): 14-16. 


\section{Razzaq Shalan Augul and Hanaa H. Al-Saffar}

Martin, J. H. 1999. The whitefly fauna of Australia (Sternorrhyncha: Aleyrodidae), a taxonomic account and identification guide. CSIRO Entomology, CSIRO, Canberra, Technical Paper, 38: 1-197.

Matile-Ferrero, D. 1988. Sternorrhyncha: Suborder Coccoidea of Saudi Arabia (Part 2). Fauna of Saudi Arabia, 9: 23-38.

Mendel, Z., Protasov, A., Fisher, N. and La Salle, J. 2004. Taxonomy and biology of Leptocybe invasa Gen. \& Sp. N. (Hymenoptera: Eulophidae), an invasive gall inducer on Eucalyptus. Australian Journal of Entomology, 43: 101-113.

Mizzi, S., Dandria, D., Mifsud, D. and Longo, N. 2009. The red palm weevil, Rhynchophorus ferrugineus (Olivier, 1790) in Malta (Coleoptera: Curculionoidea). Bulletin of the Entomological Society of Malta, 2: 111-112.

Moanas, A. M. H. and Abdul -Rassoul, M. S. 1989. First record of Dacus ciliates Loew (Diptera: Tephritidae) as a pest of cucumber in Iraq. Bulletin of the Iraq Natural History Museum, 8(2): 173-174.

Moghaddam, M. 2013. An annotated checklist of the scale insects of Iran (Hemiptera, Sternorrhyncha, Coccoidea) with new records and distribution data. ZooKeys, 334:193.

Moghaddam, M. and Bagheri, A. N. 2011. A new record of mealybug pest in the south of Iran, Phenacoccus solenopsis (Hemiptera: Coccoidea: Pseudococcidae). Journal of Entomological Society of Iran, 30(1): 67- 69.

Mohebban, S., Takallozadeh, H. M., Barahoei, H. and Madjdzadeh, M. 2015. New records of Cryptinae and Ichneumoninae (Hymenoptera: Ichneumonidae) species from Kerman provinces, Southeast Iran. Journal of Crop Protection, 4(3): 337-349.

Mokhtar, A. M. 2009. Insect pests of date palm, Current Challenges and Future Perspectives. Date palm, 38pp.

Mound, L. A. and Azidah, A. A. 2009. Species of the genus Thrips (Thysanoptera) from Peninsular Malaysia, with a checklist of recorded Thripidae. Zootaxa, 2023: 55-68.

Muniappan, R., Shepard, B. M., Watson, G. W., Carner, G., Rauf, R. A., Sartiami, D., Hidayat, P., Afun, J. V. K., Goergen, G. and Ziaur Rahman, A. K. M. 2011. New records of invasive insects (Hemiptera: Sternorrhyncha) in Southeast Asia and West Africa. Journal of Agricultural and Urban Entomology, 26(4): 167-174.

Myartseva, S. N. 1982. New data on encyrtids (Hymenoptera, Encyrtidae): Parasites of scale insects (Homoptera, Coccoidea) living on Phragmites australis. Entomologicheskoe Obozrenye, 61(1): 153-163.

Nagamine, W. T. and Heu, R. A. 2003. Citrus leafminer, Phyllocnistis citrella Stainton. Available at: http://hawaii.gov/ hdoa/pi/ppc/npa-1/npa00-01-climiner2.pdf

Navidpour, S., Hoghooghi-Rad, N., Goodarzi, H. and Pooladgar, A. R. 1996. Outbreak of Chrysomyia bezziana in Khoozestan province, Iran. Veterinary Record, 139: $217-$ 217. 
Survey with checklist of the invasive

Noss, R. F. 1990. Indicators for monitoring biodiversity: a hierarchical approach. Conservation Biology, 4: 355-364.

Norris, K. R. and Murray, M. D. 1964. Notes on the screw-worm fly Chrysomyia bezziana (Diptera: Calliphoridae) as a pest of cattle in Papua New Guinea. Technical Paper, Division of Entomology, CSIRO Australia, 6: 1-26.

O'Connor, J. P., Nash, R. and Fitton, M. G. 2007. A catalogue of the Irish Ichneumonidae (Hymenoptera: Ichneumonoidea). Occasional Publication of the Irish Biogeographical Society, 10: 1-318.

Oerke, E. C. and Dehne, H. W. 2004.Safeguarding production losses in major crops and the role of crop protection. Crop Protection, 23: 275-285.

Pimentel, D., Lach, L., Zuniga, R. and Morrison, D. 2000. Environmental and economic costs of non-indigenous species in the United States. BioScience, 50: 53-65.

Potting, R. 2009. Pest risk analysis, Tuta absoluta, tomato leaf miner moth. Plant protection service of the Netherlands, 24 pp. Available at: www.minlnv.nl.

Povolny, D. 1994. Gnorimoschemini of South America VI: identification keys checklist of Neotropical taxa and general considerations (Insecta, Lepidoptera, Gelechiidae). Steenstrupia, 20(1): 1-42.

Prishanthini, M. and Laxmi, V. M. 2009.The Phenococcus solenopsis. Department of Zoology, Eastern University, Sri Lanka. Available at: http:// www.dailynews.lk/2009/07/01/fea30.asp

Pruthi, H. S. and Mani, M. S. 1945. Our knowledge of the insect and mine pests of the citrus in India and their control. Imperial Council Agricultural Research Sciences Monograph, 16: 1-42.

Rajapaksa, N. and Spradbery, J. P. 1989. Incidence of the old world screw-worm fly Chrysomyia bezziana, on livestock vessels and commercial aircraft. Australian Veterinary Journal, 66: 94-94.

Rajulu, G. S. and Gowri, N. 1988. A comparative study of the chorion of the DDT-resistant and susceptible strains of Thrips palmi Karny. Acta Phytopathologica et Entomologica Hungarica, 23(3-4): 331-341.

Renkema, J. M., Miller, M., Fraser, H., Légaré, J-Ph. and Hallett, R. H. 2013. First records of Zaprionus indianus Gupta (Diptera: Drosophilidae) from commercial fruit fields in Ontario and Quebec, Canada. Journal of the Entomological Society of Ontario, 144: $125-130$.

Rohela, K., Jamaiah, I., Amir, L. and Nissapatorn,V. 2006. A case of auricular myiasis in Malaysia. Southeast Asian Journal of Tropical Medicine and Public Health, 37: 91-94.

Sasscer, E. R. 1915. Important insect pests collected on imported nursery stock in 1914. Journal of Economic Entomology, 8: 268-270. 


\section{Razzaq Shalan Augul and Hanaa H. Al-Saffar}

Sharaf, N. S. and Meyerdirk, D. E. 1987. A review of the biology, ecology and control of Nipaecoccus viridis (Homoptera: Pseudococcidae). Miscellaneous Publications of the Entomological Society of America, 66: 1-18.

Skelley, P. E. 2012. The asiatic garden beetle, Maladera castanea (Arrow 1913) (Coleoptera; Scarabaeidae), a white grub pest new to Florida. Pest Alret, 2 pp. Available at: https://www.freshfromflorida.com/content/download/23855/486011/maladeracastanea.pdf

Spradbery, J. P. 1992. A manual for diagnosis of screwworm fly, Department of primary Industries and Energy, CSIRO Division of Entomology, Canberra, Australia, iv + $62 \mathrm{pp}$

Stainton, H. T. 1856. Descriptions of three species of Indian Micro-Lepidoptera. Transactions of the Entomological Society of London (n.s.), 3: 301-304.

Steck, G. J. 2006. The mediterranean fruit fly Ceratitis capitata (Wiedemann) (Diptera: Tephritidae). Pest Alert, 4pp. Available at: https://www.freshfromflorida.com/content/download/66416/1601214/Pest_Alert__Ceratitis_capitata,_Mediterranean_Fruit_Fly.pdf

Stocks, I. C. 2010. Nipaecoccus viridis (Newstead), a new exotic mealybug in South Florida Coccoidea: Pseudococcidae). Pest Alert, 4pp. Available at: https://www.freshfromflorida.com/content/download/66447/1601512/Pest_Alert__Nipaecoccus_viridis,_a_New_Exotic_Mealybug.pdf

Sutherst, R. W., Spradbery, J. P. and Maywald, G. F. 1989. The potential geographical distribution of the old world screw-worm fly, Chrysomyia bezziana. Medical and Veterinary Entomolgy, 3: 273-280.

Sundararaj, R. 1999. Redescription and a new host record for Aleuroclava jasmini (Takahashi) from India. Indian Journal of Entomology, 61(2): 192-194.

Tanaka, H. and Tabata, J. 2014. A new record of Phenacoccus solenopsis Tinsley, 1898 from Kyushu District, Japan. Japanese Journal of Entomology, 17(3): 119-120.

Tinsley, J. D. 1898. Notes on coccidae, with description of new species. The Canadian Entomologist, 30:317-320.

Urbaneja, A., Vercher, R., Navarro, V., Garcı'a Marı', F. and Porcuna. J. L. 2007. La polilladeltomate, Tuta absoluta. Phytoma España, 194:16-23.

Usinger, R. L. 1966. Monograph of Cimicidae. Thomas Say Foundation, vol. 7. Entomological Society of America, College Park, MD, 572pp.

van der Linde, K., Steck, G. J., Hibbard, K., Birdsley, J. S., Alonso, L. M. and Houle, D. 2006. First records of Zaprionus indianus (Diptera: Drosophilidae), a pest species on commercial fruits from Panama and the United States of America. Florida Entomologist, 89: 111-121. 


\section{Survey with checklist of the invasive}

White, I. M. 2002. Identification of peach fly, Bactrocera zonata (Saunders). In: The Eastern Mediterranean. The Natural History Museum London, UK, $21 \mathrm{pp}$.

White, I. M. 2006. Taxonomy of Dacinae (Diptera: Tephritidae) of Africa and the Middle East. African Entomology Memoir, 2: 1-156.

White, I. M. and Elson-Harris, M. M. 1994. Fruit flies of Economic significance. There identification and bionomics. CAB International, UK, 608pp.

White, I. M. and Gooder, K. F. M. 2009. African Dacus (Diptera:Tephritidae); new species and data, with particular references to the Tel Aviv University collection. Zootexa, 2127: -49 .

Wylie, F. and Speight, R. 2012. Insect pests in tropical forestry. CABI Publishing, Wallingford, $365 \mathrm{pp}$.

Yassin, A. and David, J. R. 2010. Revision of the Afrotropical species of Zaprionus (Diptera, Drosophilidae), with descriptions of two new species and notes on internal reproductive structures and immature stages. ZooKeys, 51: 33-72.

Yassin A., Capy, P., Madi-Ravazzi, L., Ogereau, D. and David J. R. 2008. DNA barcode discovers two cryptic species and two geographical radiations in the invasive drosophilid Zaprionus indianus. Molecular Ecology Resources, 8(3): 491-501.

Yousuf, M., Tayyib, M. and Shazia, S. 2007. Mealybug problem on cotton in Pakistan. Pakistan Entomologist, 24: 49-50.

Zaid A. 1999. African palm weevil, Rhynchophorus phoenicis F. attack on date palm in the Republic of South Africa and Zimbabwe. Middle East Red Palm Weevil Workshop, 26-29 January, 1999; Cairo-Egypt.

Zumpt, F. 1965. Myiasis in man and animal of the old world. Butterworths, London, Xvi+267pp. 
Razzaq Shalan Augul and Hanaa H. Al-Saffar

Bull. Iraq nat. Hist. Mus.

June, (2019) 15 (3): 343-361

\section{مسح مع قائمة مرجعية للحشرات الدخيلة للعراق}

رزاق شعلان عكل و هناء هاني الصفار

قسم الحشرات و اللافقريات، مركز بحوث و متحف التأريخ الطبيعي،جامعة بغداد، بغداد، العباد العراق

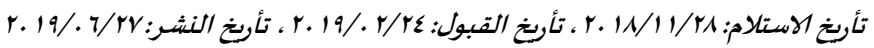

\section{الخلاصة}

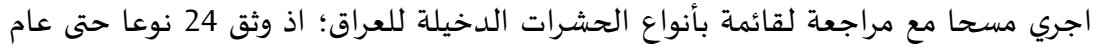

1 ا ـ خ خلال التحريات الحالية. ذكر التوزيع الجغرافي، والاسماء الشائعة و مردافاتها لجميع الانواع.

شملت التحريات الحالية جميع الأنواع الدخيلة في العراق ، بما فيها تلك التي لم تجمع خلال

$$
\text { هذه الدراسـة. }
$$

